\title{
A REVISIONIST HISTORY OF TORT LAW: FROM HOLMESIAN REALISM TO Neoclassical Rationalism, alan Calnan (Durham, N.C.: Carolina ACADEMiC Press, 2005)
}

Historical inquiry, Michael Oakeshott cautioned, entails more than mere explanation of events. It extends to their discovery.' And, since discovery implies exploration, the historian cannot presuppose the existence or parameters or even the importance of historical events. History must aspire, at least in part, to reconstruct as factually accurate a past as surviving evidence permits. So understood, the historian's task is that of disciplined forensic verification and sensible inference.

Legal history is replete with lessons in the risks of proceeding otherwise - and, in particular, of treating past events as received intellectual constructs instead of as the reconstructed product of objectively discernible facts. One of the most notorious early examples was James Tyrrell's General History of England, ${ }^{2}$ which maintained that the common law had subsisted in a fundamentally unaltered state from an age antedating the Norman Conquest, enshrining an ancient, quasi-parliamentary constitution. With the gradual development of careful historical research, however, the nature of feudalism became better understood and the idea of an ancient constitution became something of an embarrassment. ${ }^{3}$ (Hence the appeal of John Locke's break with previous Whig tradition, when he based his arguments entirely on reason and on "natural rights.")

Tyrell had been seduced by a romantic legal historicism, born of the idea that legal history is a deterministic process governed by inexorable laws that operate independently of human activity or will. As such, it operates in contradistinction to historicity's non-mythic and evidence-based elucidation of the past. Efforts such as Tyrrell's to confer historical veracity or significance upon particular perspectives on the law, after all, inevitably entail the imposition of the historicist's own preconceptions, and conversely the avoidance of intrusion from available historical evidence. Stating history peremptorily, historicists (in the words of Mrs. Malaprop) "anticipate the past."

In A Revisionist Histony of Tort Law: From Holmesian Realism to Neoclassical Rationalism, ${ }^{5}$ Alan Calnan argues that much of what tort lawyers in the Anglo-American tradition have taken for over a century to be the history of their ficld is - regrettably, in his opinion - a product of a peculiar brand of historicism informed by the preconceptions of Oliver Wendell Holmes, Jr. This insight represents, on its own, nothing new: it is common knowledge among tort historians that the elucidations of both Holmes and Sir Frederick

' Michael Oakeshott, "Historical Events" in Michael Oakeshott, ed., On History and Other Essays (Indianapolis: Liberty Fund, 1999) 49 at 49-57. Sec also Michacl Oakeshott, "Duncan Forbes: The Liberal Anglican /dea of Hisfory." Book Review (1952) 6 Cambridge Joumal 248.

: General Ilistory of England. Boih Ecclesiastical and Civil (L.ondon: J. Harris, in Little Britain; R. Knaplock, in St. Paul's Church-Yard; A. Bell, in Comhill; and T. Cockerill, at the comer of WarwickLane, in Pater-Noster-Row, 1697). Historical Thought in the Seventeenth Cenury (New York: Cambridge University Press, 1957). Richard Sheridan, "The Rivals" in Cecil Price, ed., Sheridan Plays (London: Oxford University Press, 1975) 3 at 58.

" Durham, N.C.: Carolina Academic Press, 2005. 
Pollock were coloured by their own perception of the law's historical foundation ${ }^{6}$ (although, as Calnan emphasizes, their reputations remain largely intact). Moreover, it would hardly be surprising to learn that the opinions on history of these influential figures - Holmes in particular - would have been widely read, as few lawyers at the beginning of the twentieth century would have been oblivious to the common law's dependence on its historical roots. While the old forms of action were dead, they were, as Frederic William Maitland quipped, still ruling from the grave. ${ }^{?}$

Calnan's thesis goes further than mere criticism of Holmes' historicism, but the completeness of that critique alone makes the read worthwhile, since tort lawyers have long been swayed by Holmes' preconceptions of tort law's history, and almost all tort lawyers and certainly all of them in the U.S. - have relied heavily on Holmes' work. Calnan, like most serious students of Holmes, ${ }^{8}$ conceptualizes Holmes' theory of tort law as consisting of two distinct phases. First, in "The Theory of Torts," Holmes engaged in a formalist search for scientific principles of tort law and a coherent organizational structure, which he found in the classification of torts between fault-based and no-fault torts." The latter category posed a problem, as Holmes had famously railed against no-fault liability schemes, arguing in essence that the law was tied to fixed deontological principles privileging rights and duties over shifting public policy.

Forced to revise his theory in The Common Law," Holmes now argued that, instead of consigning most torts to the no-fault category (as he had done in "The Theory of Torts"), tort lawyers should understand fault as the general rule and strict liability as the exception. This conversion to "fault" is not as important to Calnan as the rationale that Holmes posed, which amounted to a "theory of legal evolution."'2 Relying on Anglo-Saxon authorities as documenting an amoral no-fault system, he conceived of tort law as having originated from rules reflecting primitive urges of vengeance and blame, which represented aspects of a general rule of strict liability. As centuries passed, these nules were abolished or preserved, in accordance with governing public policy that increasingly tended away from strict liability. That is, as tort law evolved, it shifted "from a general moral standard into many specific rules of social convenience"13 that, at least generally, privileged a fault threshold.

By claiming for his jurisprudence an historical fidelity, Holmes made it unassailable. Remarkably, "[n]o one actually stopped to evaluate, let alone challenge, the quality of his

See, for a recent instance, David Ibbetson, "Historical Research in Law" in Peter Cane \& Mark Tushnet, cds., The Oxford Handhook of l.egal Studies (Oxford: Oxford University Press, 2003) 863 at 865. G. Edward White also criticized Holmes' historiographical methodology in Justice Oliver Wendell Holmes: Law and the Imer Self (Oxford: Oxford University Press, 1993).

F.W. Maitland, The Forms of Action at Common Law, ed. by A.H. Chaytor \& W.J. Whittaker (Cambridge: Cambridge University Press, 1969) at I.

- See e.g. Alber W. Alschuler, Law Without Values: The Life, Work and Legacy of Justice Iloimes (Chicago: University of Chicago Press, 20000) at 262. n. 182.

Oliver Wendsll Holmes, "The Theory of Torts" (1873) 7 Am. L. Rev. 652.

10 Calnan, supra note 5 at 6, 12.

" Oliver Wendell Holmes, The Common Low, ed. by Mark DeWolfe Howe (Cambridge, Mass.: Belknap Press, 1963) [Holmes, The Common Law].

1: Calnan, supra note 5 at 21.

13 Ibid. 
research or the manner in which he used it."14 And what was the source of his historical claim? As Holmes magisterially pronounced in "The Path of the Law,"15 it was to be found in "the oracles of the law" in which "are gathered the scattered prophesies of the past."16 More specifically, it constituted "a body of reports, of treatises, and of statutes, in this country and in England, extending back for six hundred years, and now increasing annually by hundreds." " All of these, Calnan explains, were viewed by Holmes as documenting parts of a single, evolving organism, which he parsed "for fragments of authority to complete his jurisprudential mosaic."18 In short, Holmes was not researching to discover a theory of tort law, but cherry-picking to affirm his theory of tort law. ${ }^{19}$

Having exposed Holmesian historicism, Calnan then sets out to construct his own historical account of the law of torts, employing what he calls a "comprehensive contextualism" 20 by which he discerns the law's practical and philosophical foundations through examination of the prevailing contemporary ideologies and value systems. His point is that one cannot hope to understand the law without open-mindedly seeking to understand the environment that generated it, and that this in turn requires jettisoning Holmesian presuppositions that early tort law was both positive and relative, unanchored to a common norm. This speaks to the distinction that David Ibbetson has drawn between "internal" legal history - that is, the positivist, doctrinal legal history of, inter alia, Maitland and James Barr Ames - and the more contextualized "external" legal history, " whose earliest instantiations include James Willard Hurst's The Growth of American Law: The Law Makers ${ }^{22}$ and Morton J. Horwitz's The Transformation of American Law, 1780-1860.23 That said, Calnan would phrase the distinction differently - "internal" legal history being the incomplete history that lawyers write, and "external" legal history being the comprehensive, contextual history that historians write.

Calnan's tort law history, in a nutshell, begins with Henry II and his institution of a permanent royal judiciary, a momentous event representing the genesis of the common law. At that time, and for several centuries thereafter, Calnan emphasizes, Europe (including England) was undergoing a classical revival, which influenced the thinking of that nascent judicial body. Aristotelian insights, Roman law and canon law were moulded by Thomas Aquinas into a rights-based political theory, broad enough to embrace jurisprudence. The resulting transformation was fundamental. People became viewed as having certain natural rights, to which the royal will was subordinated. Reason - both in its speculative form,

$14 \quad$ bid. at 24.

is Oliver Wendell Holmes, "The Path of the Law" (1897) 10 Harv. L. Rev. 457.

16 Jbid. at 457.

17 bid.

18 Calnan. supra note 5 at 24.

19 Calnan is a fair critic, however. and so he cites Holmes as actually acknowledging his selectivity (which makes the lack of contemporary doubters even more remarkable): "'I shall use the history of our law so far as it is necessary to explain a conception or to interpret a rule, but no further'" (Holmes. The Common Law, supra note 11 at 6 , cited in ibid. at 25).

2v Culnan, supra note 5 at 52 .

II Jbetson, supra notc 6 at 864.

3 Boston: Little, Brown \& Co., 1950

23 Cambridge, Mass.: Harvard University Press, 1977. Calnan, however, views Horwitz's effort as incomplete, criticizing its ignorance of non-economic impulses for law's historical development and its failure to "fully" explore the English heritage of U.S. tort law (see Calnan, supra note 5 at 77). 
which identified universal principles of justice, and its practical form, which applied those principles to individual cases - replaced faith as the basis for judgment. Thus, we are told, by analyzing the writings of John of Salisbury, Ranulf de Glanville, Henry de Bracton and Sir John Fortescue, we can discern an emerging, collective and artificial common law reasoning that blends Aquinas' philosophy with English moral instincts, practical experience and custom. Those statements, in turn, denote a sense of blameworthiness as the earliest basis for liability in something we recognize today as "tort." Furthermore, tort law's progression from these beginnings was not, as Holmes suggested, a mindless evolution in positivist, relativist or realist terms. Rather, it matured with reference to neoclassical concepts of naturalism, liberalism and rationalism and, in so doing, exhibited constant fidelity to faultbased liability.

My principal criticism of Calnan's book goes not to the substance of his critique of Holmes or his own understanding of tort law's history, but to format. With sub-chapters ranging from a few lines to a few pages in length, the overall presentation is disjointed, hard to follow and on occasion repetitive (I gave up keeping track of the number of times Calnan referred to reason having been the foundation of the common law, or to Aristotle having equated lawfulness with justice). And, for much of the first three-quarters of the book, the reader is distracted with a legion of hints as to tort law's Aristotelian origins, and yet it is not until the final chapters that those origins are actually described and related to his thesis.

Organizational concerns aside, Calnan's all too brief discussion of the influence of public policy ${ }^{24}$ in shaping the early law of trespass is intriguing, original and leaves the reader wanting more. Perhaps, on this subject, he might have addressed other early potential examples of public policy's formative role in the early common law of obligations, such as the common calling cases of the thireenth and fourteenth centuries. He also does not address recent criticisms that Bracton, like Holmes, was also guilty of selectiveness in his choice of authorities and that, as a result, Bracton's writings cannot be taken as a true or reasonably complete reflection of contemporary royal judicial practice. ${ }^{25}$ Conversely, Calnan's criticism of legal historians for failing to examine the substance behind tort law's historical form (including the law's intellectual roots and the philosophical impulses for its progression) is probably overstated, as it overlooks some contrasting Commonwealth scholarship, notably that of Ibbetson. ${ }^{26}$ Even U.S. scholar James Gordley's work, which would tend to support Calnan's arguments about tort law's philosophical origins, ${ }^{27}$ is not referenced. This is unfortunate, since much of what Calnan says (at length) about the tort law duty of care, for example, ${ }^{28}$ has already been said in Gordley's pithy and accessible work.

In view of the importance of Calnan's contribution, however - being to expose the fundamental intellectual delinquency that underlies Holmesian historiography (and therefore

Calnan, ibid. at 189-190.

See J.L. Barton, "The Mystery of Bracton" (1993) 14 J. Legal Hist. I; Paul Brand, "The Age of Bracton" in John Hudson, ed., The History of English Law: Cencenary Essays on 'Pallock and Mairland' (Oxford: Oxford University Press, 1996) 65.

Sec e.g. David Ibbetson, A Historical Introduction to the Law of Obligations (Oxford: Ox ford University Press, 1999).

See in particular, James Gordlcy, "Tort Law in the Aristotelian Tradition" in David G. Owen, ed., Philosophical Foundations of Tor Law (Oxford: Oxford University Press, 1995) 131.

Calnan, supra note 5 al $143-51$. 
jurisprudence) and to document tort law's historical consistency as a fault-based device my criticisms are mere quibbles. And, as to that last quibble, Calnan's analysis, to be fair, goes further than Gordley's, because Calnan demonstrates the historical accuracy of Gordley's claims to natural law's influences in tort law's development. Or, more precisely, Calnan's evidentiary weightiness carries the advantage of elaboration and, in many respects, demonstration through the "comprehensive contextualism" whose general absence from legal historical scholarship he laments.

Is Calnan right about tort law's normative origins? Of course, if we are to take Oakesholl's precaution seriously, we must each conduct our own inquiry to satisfy ourselves. Failing our taking the trouble to do so, Calnan's contribution stands as the most thorough, evidencegrounded attempt yet. We need not, however, be so reticent in judging his demolition of the conventional Holmesian view of tort law (as having evolved from a general notion of strict liability) as being both surgical in methodology and total in scope. The reader is left only to wonder why Holmes continues to carry any force, despite having been revealed as (at best) a lazy historian or (at worst) a yarn-spinner. Given some of the Supreme Court of Canada's relatively recent tort law pronouncements, however, including inconsistent policy-driven decisions on the two-stage test for duty of care $^{29}$ and on the recoverability of pure economic loss, ${ }^{30}$ one obvious explanation is that jurists educated in the public policy tradition of Lord Denning want the law to be understood as relative, policy-based and untied to enduring principle. After all, if the law can be viewed as unfettered by norms, then, as Calnan points out, "judges ... will be left to their own devices."

This suggests that the enduring importance of Calnan's contribution will be in its provocation of jurists to consider why the way in which they treat legal history matters. He demonstrates that mixing jurisprudence and history is tricky, and this should tell us something about lawyers purporting to write history, even legal history. The lawyer's common law inquiry entails, at its most practical level, a search for the helpful judicial precedent, not a faithful reconstruction of the past. The judicial inquiry is no different: Calnan's essential point about Holmes' historiography is that it was a product of that same selective search for historical authority to reinforce his own polemical opinions. Judges, after all, frequently invoke historical arguments to legitimize their pronouncements in tort cases. The modern doctrine of strict liability owes its existence, at least in part, to the (until now) unchallenged belief in tort law's early norm of liability without fault. If historical ascriptions are important, then accurate references can only promote legal continuity - itself a presupposition of the rule of law, inasmuch as rules are seen as statements of juridical principle, not judicial caprice.

Russell Brown

Assistant Professor

Faculty of Law

University of Alberta 